\title{
Los tipos iconográficos de la tradición cristiana. 4 Los Ángeles III. La música del Cielo
}

\author{
GARCÍA MAHÍQUES, Rafael (dir.) \\ Ediciones Encuentro, Fundación Juan-Miguel Villar Mir, Fundación Las Edades del Hombre, Madrid, 2018
}

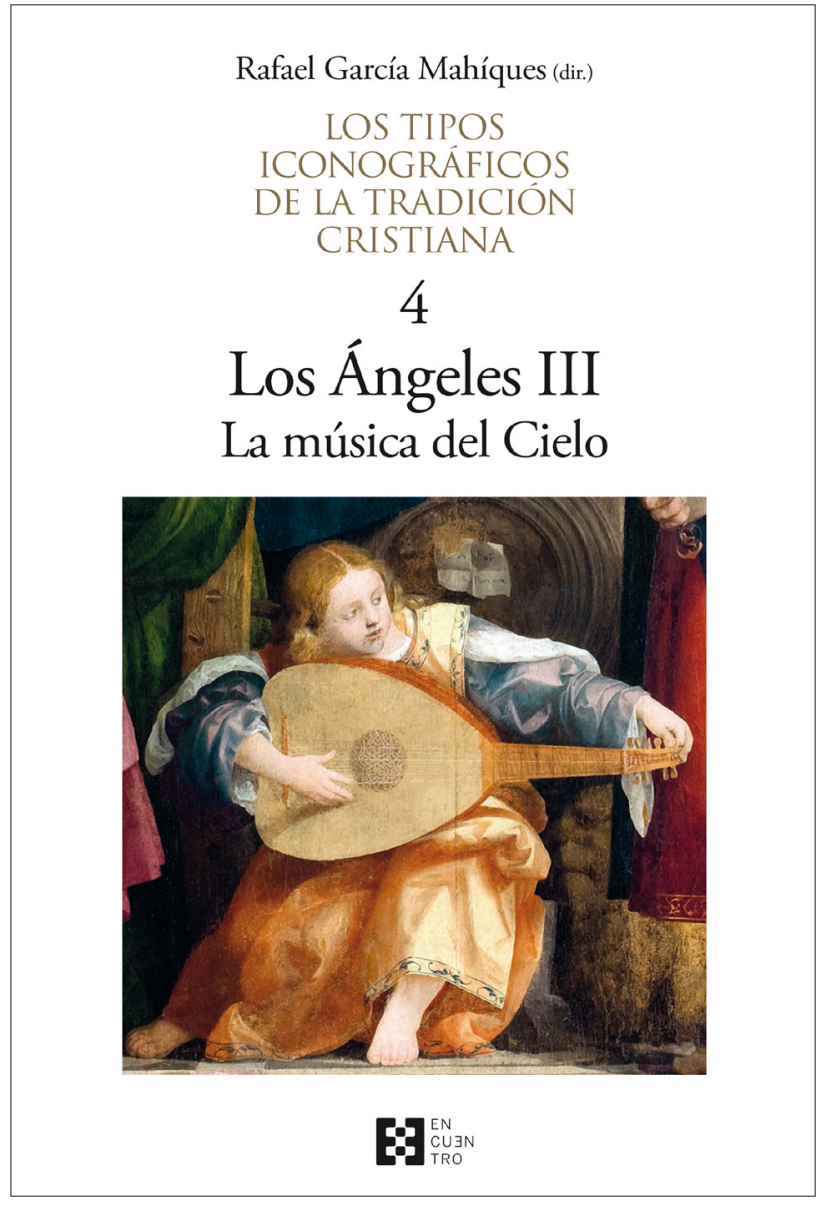

El profesor Rafael García Mahíques es, sin ningún género de dudas, uno de los máximos iconólogos de España, como lo demuestra este libro y su ya larga y sostenida trayectoria de trabajos científicos - de un gran nivel- desarrollados durante varias décadas, y acompañado casi siempre (signo muy positivo de su capacidad de trabajar en equipo) de su acreditado grupo de investigación APES. Estudios de Cultura visual (www.uv.es/apesgrup).

Es indiscutible que estamos ante un referente de la historia del arte español, cuando menos, en el terreno que él mismo ha convenido en llamar historia del arte como historia cultural (Warburg, Panofsky, Gombrich), y que él mismo plantea como una estrategia alternativa e integradora de las diferentes funciones que ejerce en la actualidad la historia del arte. Es decir, una sana y bienvenida alternativa metodológica que lo observa, lo recoge y lo aprovecha «todo» (también los tradicionales análisis formales y estilísticos: ¡qué sería de la historia del arte sin ellos!; navegaríamos en un mar de puras y a menudo vagas apreciaciones), para obtener el más gustoso néctar que ofrece y destila el amplio y erudito saber warburguiano. Una iconología, en definitiva, que bien entendida -como sin duda la percibe García Mahíques- es el «todo» holístico de la historia del arte universal. Una iconología -y a la postre una disciplina de la historia del arte- que se erige en el conocimiento omnipresente de la cultura, de nuestra cultura, y que es capaz de atrapar, conocer, saborear y explicar, de un modo cabal, utilizando la sabia narrativa warburguiana, nada más y nada menos, que hasta la misma «música del cielo» (o música ontológica de la divinidad), como reza en el subtítulo de este espléndido libro, tercero de la serie dedicada a la «representación visual de los ángeles», y cuarto de la colección «Los tipos iconográficos de la tradición cristiana», auténtica monumenta, al fin y al cabo, de las huellas más importantes y significativas, en clave angélica, de la historia occidental.

En Europa somos lo que somos, en muy buena parte, en virtud de esa herencia y tradición cristiana que lo impregna todo (no solo las esferas angélicas), aunque a veces ese «todo» resulte algo imperceptible. Una obra, pues, por ahora, 10 (10 sobre 10), la de Rafael García Mahíques, ayudado de la fina y perspicaz pluma de Candela Perpiñá García.

Una enorme contribución -e invitación- a mirarnos de nuevo en el espejo de esa sabia tradición milenaria que tanto nos ha dado, o de la que tanto hemos recibido. Solamente ese agudo deseo de rescatar y apuntalar de forma neutra y objetiva esos imperecederos valores cristianos, ya se convierte en un claro e impagable valor añadido de este 
gran libro y de esa titánica tarea intelectual emprendida por el profesor Rafael García Mahíques.

Pero examinémoslo, el libro, con algo más de detenimiento.

La introducción es sin duda el núcleo gordiano y conceptual sobre el que se fundamenta todo su contenido. Es, además, su parte más sesuda. Trata de definir lo indefinible: "los ángeles, la armonía de las esferas y la música». Algo así como el concepto de música celeste o armonía de las esferas que hunde sus raíces en la tradición oriental (ex Oriente lux). O una música entendida como una relación matemática que ejerce un papel fundamental en la organización y mantenimiento del universo, en la relación armónica del cosmos o caeli macchina. En consecuencia, como explica Isidoro de Sevilla (ca. 560-636), nada en el mundo, ninguna disciplina, ninguna iniciativa, ninguna acción, nada, «puede ser perfecta sin la música» (p. 17); incluso el mismo cielo, de acuerdo con el mismo Isidoro de Sevilla, gira bajo la influencia modular de la música armónica.

Parafraseando el Idiota de Dostoyevski, la belleza -y la música, por supuesto, rostro inequívoco de la belleza- salvará el mundo. Nada nuevo, pues -aunque aquí bellamente narrado por García Mahíques y Candela Perpiñá-, porque, como escribe la sabia Santa Hildegarda von Bingen (10981179), «la fuente de toda música es Dios, o más concretamente, el Espíritu Santo» (p. 39).

A partir de esta completa, sugerente y convincente introducción, el libro se convierte en una explosión de colorido angélico. Todo él transcurre por entre una bellísima música celestial producida por ángeles músicos cristianos, a juzgar, sobre todo, por el amplio elenco de obras de arte que ilustran -y hasta casi hacen sonar- esa música y esos envidiables instrumentos.

El libro, pues, se convierte también en una especie de tratado de musicología, y da cuenta de un sinfín de instrumentos de las épocas medieval y moderna. "La voz de la tuba [por ejemplo] representa las palabras de los ángeles cuyo enorme ruido llenaba el aire y lo estremecía» (p. 61, siguiendo la interpretación que Casiodoro, Padre de la Iglesia, hace del salmo 47). O, referidos al decisivo y debatido concepto de Juicio Final en la Europa de Miguel Ángel, observamos el modo rotundo con que en la Capilla Sixtina resuenan los siete ángeles trompeteros de la narración apocalíptica soplando con fuerza unos aerófonos de tubo recto muy similares, por cierto, a los pintados pocos siglos antes por Giotto (fig. 3, pp. 67-68).

Se expone, también, con una buena cadencia narrativa «la formación y difusión del ángel músico», bien apuntalada, entre otras fuentes, en el rico y ya citado Códice de Hildegarda (ca 1180), y su amplia difusión europea (pp. 96 y ss.). Todo trascurre por entre imágenes estremecedoras de los grandes maestros de la historia del arte universal (Luca della Robbia, Bellini, Piero della Francesca, Filippino Lippi...), de las que descuella, entre otras, una trascendente Anunciación del Greco (Museo del Prado, ca 1596-1600); aquí se observa una sutil performance (sic, p. 141) angélica; «así -escribe con sagacidad Candela Perpiñá- el flautista ha dejado de insuflar la flauta y espera el momento para tañer de nuevo, por lo cual dirige la mirada hacia la viola que, junto la espineta, ejecutaría el bajo continuo» (pp. 141-142). Esta perspicaz manera de describir el contenido musical de cada obra indica que el libro no sólo acompaña al lector en la compresión iconográfica de cada escena, sino en la interpretación y succión del «todo», angélico, polícromo, musical y trascendente, de cada obra. Abundando en la obra del Greco, es exquisita la manera de percibir cada una de las actitudes angélicas: «el cantante -identificado con un libro de partituras que indica el carácter culto de la música de los cielos- también permanece callado y marca el ritmo para quienes están tocando... una cantata de inicios del Barroco» (p. 142, fig. 13).

El libro, bello por doquier, avanza con una sistemática y bien trenzada descripción de ángeles músicos en los diferentes episodios de la historia sagrada (por ejemplo, la Natividad de la Virgen, la Educación de María, los Desposorios de María y José, la Anunciación o el amplio repertorio de la vida de Jesús). A destacar el sucinto apartado "Ángeles músicos en tipos conceptuales de la Virgen María» (pp. 338-347), donde descubrimos diversos pronunciamientos musicales en honor de la maternidad divina de la Virgen. San Juan Damasceno (675-749), por ejemplo, nos recuerda que ante María «los Principados exultan, las Dominaciones se regodean, las Potencias se alegran, los Tronos festejan, los Querubines cantan alabanzas, Ios Serafines proclaman gloria. Pues no es para ellos una gloria exigua el glorificar a la madre de la gloria» (p. 340).

Cada una de las páginas de este libro (generosa y consecuentemente bien editado por Ediciones Encuentro) se 
convierte no solo en un completo tratado iconográfico, un magnífico vademécum angélico y musical, sino también en una apoteosis de beatitud, de clímax humano y divino, y, por qué no, de permanentes, connaturales e inherentes deseos de trascendencia. Es decir, a través de la música y del mundo celeste de los ángeles músicos, en el libro de los profesores García Mahíques y Candela Perpiñá se nos invita también a aspirar a más, se nos muestra, se nos narra, se nos explica, se nos exhorta a contemplar a través de sublimes obras angélicas, mariológicas, cristológicas o hagiográficas, ese permanente anhelo de la criatura europea -e iberoamericana, aunque aquí, todavía algo más en ciernes- de «una vida más bella», en lúcidas palabras de Johan Huizinga (El otoño de la Edad Media. Estudios sobre la forma de la vida y del espíritu durante los siglos XIV y XV..., 1994, 20. a ed., p. 60). El ser humano, toda criatura humana, aspira a «una vida más bella».

En definitiva, Rafael García Mahíques y Candela Perpiñá García han escrito un libro que también contribuye a recordar, en palabras ahora de Georges Duby (San Bernardo..., 1981, p. 13), que en la decisiva etapa de la Baja Edad Media (y en el Renacimiento, según Eugenio Garin), en toda Europa: «la ética y la estética se confunden» (pulchrum et aptum, decorum et honestum) (cfr. José Enrique Ruiz-Domènec: Sentir el arte. Lectura de San Bernardo..., 2018, pp. 56-57). Es decir, lo que nos muestra y evidencia este libro es una realidad -bella y trascendente- de lo que acontecía y existía, de verdad, en la Europa medieval y moderna: un amplio deseo de una vida más bella, más plena.

Cuando se describe la Virgen entronizada con el Niño, obra del ferrarés Cosimo Tura (1474), sorprende la nada despreciable descripción formal («ángeles mancebos situados en una disposición simétrica y siguiendo un recorrido ascensional», p. 370), salpicada de agudezas visuales que perciben, por ejemplo, cómo uno de los laúdes está siendo afinado, o cómo la forma de la caja de resonancia de dos cordófonos recuerda a una lira antigua que, quizá, de forma simbólica, evoca la armonía de las esferas. Son, insisto, descripciones que contribuyen a valorar el invariable atractivo formal de la obra, además de su profundo contenido angélico y musical.

Extenso y bien desarrollado -yo diría que, esperado, porque hacía falta algo así en la historiografía española- es el apartado final dedicado a la «Presencia de la música angélica en los santos» (pp. 498-648), quienes, a pesar de su imperfección, son capaces de cantar los misterios divinos: sed tantum mystica Dei canentes (santa Hildegarda).

Me parece francamente admirable, novedoso y muy original -además de veraz- el hecho que este libro considere -y nos ayude a descubrir- que los santos también pueden ser considerados verdaderos instrumentos musicales; "considerando que la divinidad escogía a ciertos hombres y mujeres para que se convirtieran en sus instrumentos» (Elisabeth von Schönau e Hildegarda von Bingen). Es decir, a pesar de sus limitaciones, incluso de sus pecados, los santos son capaces de cantar los misterios divinos, como trompetas que cantan: qui in tuba ipsius canut, pues «una trompeta solo reproduce el sonido y no lo produce si otro no sopla en ella» (p. 499).

La autora prosigue de un modo admirable cuando asevera que «Dios recoge toda la devoción que se le profesa en la Tierra y el Cielo y lo deposita en el corazón del santo, el cual suena como un instrumento de cuerda. Y el día de San Agustín, éste se le aparece con el mismo esplendor y su corazón adquiera apariencia de una lira, con un sonido distinto" (p. 504, inspirado en el Legatus divine pietatis de Gertrud von Helfa, santa Gertrudis, 1256-1302). Apoteósico.

Los santos, además, nos cuenta Candela Perpiñá, acompañados de instrumentos y ángeles musicales fueron claves en la evangelización de Hispanoamérica, tanto por su poder adoctrinante como por su componente afectivo ( $p$. 531).

Y así, entre formidables cadencias polícromas, transcurre y concluye el libro, ahora con la visión de las celestes armonías musicales de los santos María Magdalena, Santiago el Mayor, Catalina de Alejandría, Catalina de Siena, por supuesto Cecilia y su patronazgo musical, y Francisco de Asís (Cántico del hermano Sol) y las órdenes mendicantes.

Conmovedora es, por ejemplo, la conocida imagen de San Francisco confortado por un ángel músico, de Francisco Ribalta (fig. 68, Museo del Prado), o el áurico San Francisco de Asís, de Sandro Botticelli (fig, 61, National Gallery de Londres), quien aparece «coronado por diez ángeles que tocan un salterio trapezoidal con los costados ligeramente curvados, un aerófono de tubo corto, los címbalos, un pandero con sonajas, el arpa portátil, la corneta renacentista, la flauta dulce, el laúd y un cordófono de grandes dimensiones frotado con arco y apoyado sobre el hombro» (p. 620). Cuánta delicadeza descriptiva, exactitud y precisión. 
Rafael García Mahíques -como director, coordinador y editor- ha construido un sólido libro para saber y aprender, pero sobre todo para gozar. Sería fantástico que el próximo volumen apareciera acompañado de un CD (o en MP3) con la música del cielo (ut pictura poesis; pero también «como la pintura la música»). Entonces entraríamos en cuerpo y alma dentro de ese apasionante universo celeste que nos permitiera comprobar que los santos son capaces de cantar misterios divinos y que los Principados exultan, las Dominaciones se regodean, las Potencias se alegran, los Tronos festejan, los Querubines cantan alabanzas y los Serafines proclaman gloria.
Hemos de agradecer a Rafael García Mahíques y a Candela Perpiñá García un libro como este. Un libro para tener a mano, para contemplarlo, para saborearlo. Un libro que tonifica estados de ánimo y contribuye enormemente a valorar el papel de los buenos iconólogos de nuestro país. Unos iconólogos que, con su buen saber warburguiano, intentan atrapar-y mostrarnos- el «todo» holístico -y bello- de la historia del arte universal.

Ximo Company

Universidad de Lleida 